\title{
A Conservative Disposition and Constitutional Change
}

\author{
Graham Gee* and Grégoire Webber**
}

\begin{abstract}
What is a conservative disposition? And can it supply any insights into the UK's changing constitution? We offer answers to these questions by identifying core elements of a conservative disposition and exploring how it offers contingent guidance to public lawyers striving to make sense of a changing constitution. Our goal is to show why a conservative disposition remains relevant to public lawyers, not despite but in large measure because the constitution is changing. We examine the disposition's relationship with change and review how a conservative disposition offers open-ended guidance on when to pursue change, how to pursue it, how much of it to pursue at any point in time, and what reasons should motivate it. After evaluating arguments against the relevance of a conservative disposition to constitutional thought, we relate conservative arguments to two important proposals for constitutional reform: the withdrawal of the UK from the European Convention on Human Rights and a written constitution.
\end{abstract}

Key words. conservatism, conservative disposition, problem of change, UK constitution, constitutional reform

\footnotetext{
Professor of Public Law, University of Sheffield. Email: g.gee@sheffield.ac.uk.

Canada Research Chair in Public Law \& Philosophy of Law, Queen’s University, and Visiting Fellow, London School of Economics \& Political Science. Email: gregoire.webber@queensu.ca. For comments on a previous draft, we thank Nick Barber, Richard Ekins, Martin Loughlin, Bradley Miller, Jean Thomas, Leah Trueblood, Ashwini Vasanthakumar, and Charlie Webb. We are also grateful to participants at a seminar on Aspects of Conservatism at the Blavatnik School of Government, University of Oxford (June 2018), a public law workshop at the University of Ottawa (May 2018), a conference on Conservatism, Law and Society at Northumbria University (November 2018), and a conference on History and Theory in the Development of Public Law hosted by Notre Dame Law School at their London campus (February 2019). We extend special thanks to the anonymous referees.
} 


\section{Introduction}

What is a conservative disposition? And can it supply any insights into a UK constitution distinguished in recent years by rapid and far-reaching change? We offer initial answers to these questions. Our starting point is that conservatism presents a curious contrast within the study of public law in the UK. On the one hand, it is commonplace for arguments, policies, cases, individuals, and even large spans of constitutional history to be characterised as 'conservative'. On the other hand, these are often no more than throwaway characterisations, with little reflection on what it means to describe something or someone in this way. ${ }^{1}$ Not only are answers to questions about the nature, commitments, and limits of conservatism not forthcoming, but the questions themselves are seldom even posed. We suspect that, as a result, conservatism - and especially a conservative disposition - is poorly understood within constitutional thought. In this essay, we identify core elements of a conservative disposition before explaining why it offers arguments relevant to public lawyers striving to make sense of the UK's changing constitution.

Public lawyers are not alone in their general neglect of conservative thought. A similar pattern has been noted in political philosophy, where conservatism regularly fails to earn a place alongside philosophies and ideologies that receive sustained study, such as liberalism, socialism, libertarianism, and Marxism. ${ }^{2}$ To the extent that conservatism is examined in depth, it is often by those self-identifying as 'conservative'. ${ }^{3}$ In recent years, there have been other accounts— - critical $^{4}$ as well as celebratory ${ }^{5}$ - but often these are aimed primarily at popular audiences. That it has been predominantly conservatives writing about conservatism might reinforce the absence of much interest among those who do not identify as 'conservative'. More

\footnotetext{
'An exception is Martin Loughlin, who points to conservatism's role in shaping the intellectual history of UK public law: Martin Loughlin, Public Law and Political Theory (OUP 1992).

${ }^{2}$ See Martin Beckstein and Francis Cheneval, 'Conservatism: Analytically Reconsidered' (2016) 99 Monist 333, 333. See also FA Hayek, 'Why I am Not a Conservative' in The Constitution of Liberty (Routledge 2006) 355, in which he doubts 'whether there can be such a thing as a conservative political philosophy'.

${ }^{3}$ See eg Michael Oakeshott, 'On Being Conservative' [1962] in Rationalism in Politics and Other Essays (rev edn, Liberty Fund 1991); Russell Kirk, The Conservative Mind (Faber and Faber 1954).

${ }^{4}$ See eg Ted Honderich, Conservatism (Penguin 1991); Ted Honderich, Conservatism: Burke, Nozick, Bush, Blair? (Pluto Press 2005); Corey Robin, The Reactionary Mind: Conservatism from Edmund Burke to Sarah Palin (OUP 2011).

${ }^{5}$ See eg Roger Scruton, How to be a Conservative (Bloomsbury 2014); Roger Scruton, Conservatism: Ideas in Profile (Profile Books 2017); Kieron O'Hara, Conservatism (Reaktion 2011).
} 
pointedly, for many, conservatism appears reducible to opposition to 'the progressive view of humankind and society'. ${ }^{6}$ As will become clear, it is possible to conceive of conservatism in ways divorced from what some regard as its unwelcome associations.

Two further reasons for the general lack of academic engagement bear mention. ${ }^{7}$ First, it might be suggested that conservative thought is not the most fertile ground for the analytic reflection that characterises academic inquiry. Conservatism is often said to eschew theorising about human affairs, at least insofar as systematic statements and abstract principles are viewed as unreliable guides when trying to make sense of the complex and concrete traditions of behaviour that shape political communities. ${ }^{8}$ It might be tempting to assume that little scope therefore exists for systematic reflection or analytical probing about a way of thinking that itself prioritises practical knowledge over theoretical reflection. ${ }^{9}$ Our view is that, to the contrary, conservative thought has much to offer reflective inquiries into human affairs. ${ }^{10}$ Second, there may be some who assume that the study of conservatism is of interest only to those whose views lean to the political right. The popular ascription of the small-c label 'conservative' to many right-of-centre parties, together with the fact that some such parties are called capital-C 'Conservatives', encourages this assumption. ${ }^{11}$ But names of parties bear no more than a casual relationship to

\footnotetext{
${ }^{6}$ Noël O’Sullivan, 'Conservatism' in Terence Ball and Richard Bellamy (eds), The Cambridge History of Twentieth Century Political Thought (CUP 2003) 151. For a biting critique of conservatism, and its relation to social and political inequality in particular, see Robert Eccleshall, 'English Conservatism as Ideology' (1977) 25 Pol Stud 62.

${ }^{7}$ See Michael Freeden, Ideologies and Political Theory: A Conceptual Approach (OUP 1996) 317-21.

${ }^{8}$ See Michael Oakeshott, 'Rationalism in Politics' in Rationalism in Politics and Other Essays (rev edn, Liberty Fund 1991).

${ }^{9}$ Aiding such an (erroneous) assumption is that the fact that conservatism is (wrongly) associated with few 'great texts': EHH Green, Ideologies of Conservatism (OUP 2002) 14. This supposed absence of a large and distinct body of work that can be studied by successive generations might create the impression that conservatism lacks intellectual heft. See eg W H Greenleaf, The British Political Tradition: Volume 2The Ideological Heritage (rev edn, Routledge 2003) 189-90. This is unfortunate: conservatism has produced more 'great texts' than commonly assumed, including by Burke, Hegel, Hume, Oakeshott, and perhaps Descartes.

${ }^{10}$ For the suggestion that more scope exists for systematic reflection on conservatism than generally acknowledged, see Oakeshott, 'On Being Conservative' (n3) 407; John Kekes, A Case for Conservatism (Cornell UP 1998) 2-3; Beckstein and Cheneval (n2).

${ }^{11}$ Yet, many parties on the right pursue radical policies at odds with conservative evaluations, whilst some parties on the left demonstrate a conservative posture on some policy issues. For discussion whether the UK Conservative Party had abandoned conservatism by the close of the twentieth century, see Green (n9); John Ramsden, 'Political Parties: Conservative Politics and Constitutional Ideology' in Robert Blackburn (ed), Constitutional Studies: Contemporary Issues and Controversies (Mansell 1992) 79. For a striking example of a conservative disposition within parts of the Labour Party, see its constitutional
} 
philosophies of the same or similar name, and the study of political thought is misdirected if folded into an examination of a namesake party. For our part, we do not equate the conservative disposition with any one party or point on the political spectrum. ${ }^{12}$

There are more specific reasons that may account for the relative inattention of UK public lawyers. Above all, it is possible that public lawyers tend to assume that whatever insights conservatism offers apply only to the 'old' customary constitution that resembled, in Edmund Burke's terms, an 'entailed inheritance'13 of institutions, practices, and laws, which in turn reflected and reinforced stability, longevity, tradition, continuity, evolutionary change, and the 'brutal pragmatism' ${ }^{14}$ of whatever works. It is perhaps less obvious that conservative thought has much to say about the emerging 'new' constitution and its association with rapid change, the prioritising of principle over practice, the weakening of custom, the fracturing of the unitary state, and the complex interplay of domestic law and international legal regimes. ${ }^{15}$ Not only does the UK's constitution no longer have such strong connections with history, pragmatism, and 'the way things were', but many public lawyers no longer revere traditional ways of doing things. ${ }^{16}$ For much of the last century, most public lawyers shared a basic respect for the constitution's historic institutions and practices. Today a reforming spirit has taken hold. ${ }^{17}$

We argue that conservative thought has something significant to offer public lawyers even within the so-called 'new' constitution, and as a partial antidote to this reforming spirit. Our goal is to show why what we term 'a conservative disposition'

policy for much of the last century, which seemed to be shaped to varying degrees by conservative insights. See Peter Dorey, The Labour Party and Constitutional Reform: A History of Constitutional Conservatism (Palgrave Macmillan 2008).

${ }^{12}$ See also GA Cohen, 'Rescuing Conservatism: A Defence of Existing Value' in R Jay Wallace, Rahul Kumar and Samuel Freeman (eds), Reasons and Recognition: Essays on the Philosophy of T.M. Scanlon (OUP 2011) 203; Roger Scruton, The Meaning of Conservatism (3rd edn, Palgrave Macmillan 2001) 5; Torbjörn Tännsjö, Conservatism For Our Time (Routledge 1990) ix.

${ }^{13}$ Edmund Burke, Reflections on the Revolution in France (first published 1790, Penguin 2004) 119.

${ }^{14}$ Nevil Johnson, Reshaping the British Constitution: Essays in Political Interpretation (Palgrave Macmillan 2004) 10.

${ }^{15}$ Loughlin's influential intellectual history of public law-which maps a rivalry between 'conservative normativist' and 'liberal normativist' approaches, punctuated by the rise and fall of the 'functionalist style'-perhaps reinforces the tendency of some public lawyers to associate conservative thought with the 'old' constitution. See Loughlin (n1).

${ }^{16}$ See Ferdinand Mount, The British Constitution Now: Recovery or Decline? (Heinemann 1992) 32; Martin Loughlin, The British Constitution: A Very Short Introduction (OUP 2013) 105-118.

${ }^{17}$ See Graham Gee and Grégoire Webber, 'Rationalism in Public Law' (2013) 76 MLR 708. 
remains relevant to public lawyers no matter their ideological inclinations, and not despite but in large measure because the UK's constitution is changing. We begin by explaining why we conceive of conservatism as a 'disposition' (section 2). Our sense is that this disposition is not well understood, and is all too often reduced to misleading simplifications concerning its relationship with change, which tends to be unhelpfully depicted as negative and oppositional. We explore how this disposition offers open-ended guidance in response to 'the problem of change': that is, when to pursue change, how to pursue it, how much of it to pursue at any point in time, and what reasons should motivate it (section 3). This disposition responds to the problem of change by contributing conservative arguments that are often overlooked in debates about political and legal reform. We then review criticisms of this disposition (section 4), before explaining its special place in UK constitutional thought (sections 5). Once dominant, the conservative disposition no longer enjoys its traditional hold on the constitutional imagination. We regret its eclipse within constitutional thought, the result of which is to underplay the importance of conservative arguments in assessing the case for change. We conclude by relating conservative arguments to recent proposals for reform, arguing that public lawyers should take conservative arguments seriously when confronting the problem of constitutional change (section 6).

\section{Conservatism as a Disposition}

There are a number of ways to conceive of conservatism. Among them, it can be understood as a philosophy, an ideology, and a doctrine. ${ }^{18}$ Each frame draws out a way in which conservatism is an important current within political thought. Thinking of conservatism as a philosophy underscores its idea-orientation, isolating ideas about human nature, society, politics, law, and government. Thinking of it as an ideology draws out its collective dimension as a recurring pattern of political thought that has appealed to sizable groupings through time. Conceiving of conservatism as a doctrine isolates the familiar sense in which it can be expressed as

\footnotetext{
${ }^{18}$ Some have denied that conservatism is an ideology, in large measure due to conservatism's relationship to end-defined political positions or ideals of a good society, reviewed later in this section. Others, like Huntington, accept the ideological label by opposing conservatism's 'situational' ideology to 'ideational' ideologies: Samuel P Huntington, 'Conservatism as an Ideology' (1957) 51 Am Pol Sci Rev 454. For discussion, see Martin Beckstein, 'What does it take to be a true conservative?' (2015) 5 Global Discourse 4, 5-8.
} 
policy propositions aimed at coordinating political action and informing government programmes. In these overlapping conceptions, conservatism is typically informed by accounts of duty, authority, and obedience; the importance of family, community, and religion; the fallibility of human nature; the standing of tradition in human affairs; the degree of malleability of a political community to reform; the relative merits of theoretical and practical knowledge in the conduct of political affairs; the place of political or social ends in political action; and the significance of natural and social inequalities between persons, among others.

Conservatism can also be conceived of as a disposition, and it is this conception to which we appeal. Speaking of conservatism in dispositional terms is common within conservative thought, ${ }^{19}$ but only rarely is it subject to sustained analysis. ${ }^{20}$ In this and the following sections, we articulate core elements of a conservative disposition and respond to critiques of it. In its dispositional conception, conservatism resembles a 'posture',21 'standpoint',22 'temper',23 'bias',24 'propensity',25 'outlook',26 or 'attitude'. ${ }^{27}$ As we explain, however, this is not an unthinking or (merely) behavioural, cognitive, or character trait; it rests upon a set of contestable intellectual commitments about the value of standing arrangements, human reasoning, and the complexity of human organisation. The arguments supplied by these commitments show how each one of us can reason conservatively, no matter our other philosophical or political commitments. ${ }^{28}$ More particularly, this

\footnotetext{
${ }^{19}$ See eg Oakeshott, 'On Being Conservative' (n3) 407; Robert Shuettinger, The Conservative Tradition in European Thought (Putnam 1970) 12 ('Conservatism is not an ideology or a firm set of doctrines on man and the universe. We will be nearer the truth if we view conservatism as a disposition').

${ }^{20}$ Two notable exceptions are Geoffrey Brennan and Alan Hamlin, 'Analytic Conservatism’ (2004) 34 BJ

Pol S 675 and Kieron O’Hara 'Conservatism, Epistemology, and Value' (2016) 99 Monist 423, 430.

${ }^{21}$ Brennan and Hamlin, 'Analytic Conservatism' (n20).

${ }^{22}$ Andy Hamilton, 'Conservatism' in Edward N Zalta (ed), The Stanford Encyclopaedia of Philosophy (1 August 2015) <https://plato.stanford.edu/entries/conservatism/> accessed 26 February 2019.

${ }^{23}$ Anthony O'Hear, 'Conservatism' in Edward Craig (ed), Routledge Encyclopedia of Philosophy (1st edn, Routledge 1998) vol 2, 608; Oakeshott, 'On Being Conservative’ (n3) 411.

${ }^{24}$ Brennan and Hamlin, 'Analytic Conservatism' (n20). For reservations with the behavioural and other connotations of the word 'bias', see Geoffrey Brennan and Alan Hamlin, 'Practical Conservatism' (2016) 99 Monist 336, 338 and Kieron O’Hara 'Conservatism, Epistemology, and Value' (2016) 99 Monist 423, 430 .

${ }^{25}$ Oakeshott, 'On Being Conservative' (n3) 408.

${ }^{26}$ Ernest Young, 'Rediscovering Conservatism: Burkean Political Theory and Constitutional Interpretation' (1994) 74 NCLRev 619, 624.

${ }^{27}$ Cohen (n12) 207; Oakeshott, 'On Being Conservative' (n3) 409.

${ }^{28} \mathrm{We}$ are here making a general claim, as we recognise that some normative frameworks speak in great detail about processes for deciding about change (e.g. democratic frameworks), but not about the calculus of change, which is our focus in this essay. As will become clear, our focus is on highlighting the
} 
disposition entails a certain approach to change, and it is by thinking in dispositional terms that it is possible to grasp the reasons for conservatism's basic confidence in the gradual improvement of tried and tested arrangements. A conservative disposition does not exhaust all of the multiple strands to conservatism, ${ }^{29}$ but it expresses three overlapping themes recurrent throughout conservative thought: traditionalism, scepticism, and organicism. ${ }^{30}$

We introduce these themes here and elaborate on them in the next section. The first is an attachment to established arrangements, together with a resistance to precipitate and wholesale change (traditionalism). This attachment to the tried and tested is informed by a disposition to maintain things as they are because of an appreciation of their value - a value that commands a certain loyalty. The associated resistance to change is grounded in the regret that accompanies the loss of existing valuable arrangements. ${ }^{31}$ This relationship to change is reinforced with a sense that a community's identity is intertwined with some of what now exists, such that certain changes are inconsistent with the continuity that gives us, individually and collectively, a sense of self.

A second main theme is that political wisdom is found in the accumulated experience of the community, with abstract reasoning an unreliable guide to political action because of its inability to take full account of the complexities of social practices (scepticism). Resistance to change can be grounded in scepticism regarding the promise of reforms, whereby many reformers are quick to exaggerate intended benefits and slow to identify risks of unintended consequences. This theme

conservative calculus that is (or at least ought to be) engaged when proposals for change are considered. This calculus becomes especially relevant when arguments about whether to pursue a substantive change (eg 'replace A with B') are at the fore. Those arguments are typically conducted by reference to normative frameworks. These normative frameworks dominate much academic thought, with insufficient attention paid, we argue, to the conservative calculus that we review. Thinking about the conservative disposition does not deny the importance of these normative frameworks, but aims to explain how conservative reasoning complicates the assessment of the cases for change brought into sharp relief by those normative frameworks.

${ }^{29}$ On various interpretations of conservatism, see Andrew Vincent, Modern Political Ideologies (2nd edn, Blackwell 1995) 62-93; Anthony Quinton, The Politics of Imperfection: The Religious and Secular Traditions of Conservative Thought in England from Hooker to Oakeshott (Faber and Faber 1978). ${ }^{30}$ There is an imperfect overlap between these three themes and Brennan and Hamlin's analytical distinctions between what they term adjectival, nominal (substantive), and practical conservatism. See Brennan and Hamlin, 'Analytic Conservatism' (n20); Geoffrey Brennan and Alan Hamlin, 'Conservative Value' (2016) 99 Monist 352; Brennan and Hamlin, 'Practical Conservatism’ (n24). For criticism, see Beckstein, 'What does it take to be a true conservative?' (n18).

${ }^{31}$ Scruton, How to be a conservative (n5) xiii. 
emphasises that the knowledge required for successful political action is found not in abstract speculations of this or that theorist, but in the concrete traditions that reflect the accrued wisdom of the community as a whole. ${ }^{32}$ Scepticism thus reinforces the centrality of traditionalism within conservatism: it takes political wisdom to be 'embodied, above all, in the deposit of traditional customs and institutions that have survived'. ${ }^{33}$ In its exaggerated formulations, this theme criticises the utopian promise of the power of theoretical reason. In its more careful formulations, it cautions against the imperfections of human reasoning, given the deep complexity of human affairs and the imperfect ability of humans to grasp all of the nuances that inform human interaction. In the political domain especially, this disposition privileges the wisdom found in the fruits of experience and what Burke called the 'latent wisdom of prejudice', being the 'untaught feelings' and 'mass of predispositions' supplied by the community over time. ${ }^{34}$ These modes of knowledge cannot be fully rationalised, which is not to deny their reasonableness: they are sources of knowledge in the management of human affairs that cannot be fully summarised or taught. ${ }^{35}$

A third theme views society as an organic whole that develops within the context of inherited institutions (organicism). This emphasises that a political community is a complex whole comprised of individuals whose relationships with each other are facilitated by shared histories and cultures that find expression in inherited institutions themselves not wholly the product of planning. The conservative theme of organicism does not reduce the individual to a dispensable unit of a bigger whole; rather, it denies that a community is an experiment for a social engineer. Individuals are grounded in, and their identities formed within, specific institutions, ${ }^{36}$ with those institutions valued not only for any primary purposes they were designed to fulfil, but also for contributing to social identity and shared affiliations. Stressing the intricate nature of institutions cautions against precipitate changes to their interconnected parts. In this way, this third theme complements the first two: viewing a historically evolved community as a complex whole, where individuals

\footnotetext{
${ }^{32}$ Quinton (n29) 16-17.

${ }^{33}$ Quinton (n29) 16-17.

${ }^{34}$ Burke (n13) 183. See generally JGA Pocock, 'II. Burke and the Ancient Constitution-A Problem in the History of Ideas' (1960) 3 Historical J 125.

${ }^{35}$ See Gee and Webber (n17) 713-15.

${ }^{36}$ Quinton (n29) 16.
} 
relate to each other within inherited institutions, reinforces a basic appreciation of the value of the prevailing institutions (traditionalism) and the political wisdom embodied within them (scepticism). It might be suggested that this theme is not analytically distinct from traditionalism and scepticism, but is instead a practical application of their central insights to the conceptualization of the political community. There is something in this: the core themes are related and overlapping, with blurred edges between them and, indeed, it is chiefly for this reason that we speak of conservative 'themes' rather than claims or tenets, which might imply more rigid analytical boundaries. That said, it is useful to spotlight organicism as a core theme, insofar as it underscores the special weight conservatism ascribes to institutions in furnishing order, structure and continuity. ${ }^{37}$

Our suggestion, then, is that a conservative disposition is best understood in terms of these three themes and their evaluations of the status quo and the case for change. ${ }^{38}$ This disposition is generally applicable across a spectrum of human affairs. It has relevance for individuals, and expresses assessments of change exhibited by any one person to varying degrees, at different times and in different situations. It will not be a person's only disposition and will sit alongside and compete with others, which will identify the case for change that the conservative disposition helps evaluate. A person may embrace a conservative disposition and, without contradiction, be intolerant of injustice and optimistic about the future. ${ }^{39}$ Our focus in this essay is on a conservative disposition's relationship to political affairs and its special relevance for political action (traditionalism), political knowledge (scepticism) and political community (organicism). As we explore below, this disposition is especially relevant for thinking about one aspect of political life: whether, when, how, why, and to what extent to pursue constitutional change. At some basic level, after all, most constitutions - whether a traditional customary constitution such that as found in the UK or a modern codified constitution such as found in most jurisdictions - attempt to temper change.

\footnotetext{
${ }^{37}$ See Philip Norton, 'The Constitution' in Kevin Hickson (ed), The Political Thought of the Conservative Party Since 1945 (Palgrave 2005) 93, 93.

${ }^{38}$ For some scholars of conservative thought, either the status quo or the case for change should be awarded priority over the other in conceptualizing conservatism, such that the resistance to change is an implication of the attachment to the status quo, or vice versa. Like Oakeshott, we do not commit to a relationship of priority: Oakeshott 'On being conservative' (n3) 411.

${ }^{39}$ Cohen argues that his account of the conservative disposition carries no implications for justice: Cohen (n12) 204.
} 
For now, what bears emphasis is that this disposition informs, often implicitly rather than explicitly, the thinking of many who would not identify as conservative. It has been embraced across the political spectrum, with Gerald Cohen maintaining that 'everyone who is sane has something of this disposition'. ${ }^{40}$ The compatibility of a conservative disposition with a variety of political commitments is due in part to its relationship with 'end-defined political positions'.41 Unlike many intellectual commitments, a conservative disposition lacks what might be termed a substantive ideal'. ${ }^{42}$ In its dispositional conception, conservatism is shaped more by evaluations of prevailing arrangements and the case for change, which informs arguments towards whether, how, when, how much, and why to reform the status quo. It is chiefly concerned not with instantiating a set of ideals but with discerning the wisdom embodied within existing arrangements. It is, in this sense, 'situational'. ${ }^{43} \mathrm{~A}$ conservative disposition recognises that identifying a substantive end is only ever 'part of the total picture'. ${ }^{44}$ It is also important to secure that end in a way informed by a reasoned account of the potential for and limits on change in a historically evolved community. It is in informing this account and so in assessing the case for change that, as explored below, a conservative disposition offers important though open-ended guidance for public lawyers.

A conservative disposition may feel unsatisfying to some, including many who may at times unknowingly embrace it in their own thought. This dissatisfaction may be because several conservative insights seem like homilies that remind 'readers what they already know, but perhaps tend to forget'. ${ }^{45}$ It may also be because this disposition is emblematic of the 'protean and, to the intellectual mind, untidy character of conservatism'. ${ }^{46}$ As will become clear, it represents a way of thinking

\footnotetext{
${ }^{40}$ Cohen (n12) 204 (emphasis in original). We agree with Cohen that everyone embraces a conservative disposition in at least some aspects of their personal or political thought, but we recognise the underlying commitments relating to political action, political knowledge, and political organisation will hold greater instinctive appeal to some rather than others.

"Brennan and Hamlin, 'Analytic Conservatism' (n20) 677.

${ }^{42}$ Huntington (n18) 457. See also Scruton, The Meaning of Conservatism (n12) 1; Beckstein 'What does it take to be a true conservative?' (n18).

${ }^{43}$ Andrew Gamble, 'Oakeshott's Ideological Politics: Conservative or Liberal?' in Efraim Podoksik (ed), The Cambridge Companion to Oakeshott (CUP 2012) 153, 163.

"Brennan and Hamlin, 'Analytic Conservatism' (n20) 678-79.

${ }^{45}$ Kekes (n10) 4.

${ }^{46}$ O'Hear (n23).
} 
about change that appeals to qualities of mind unfamiliar to the end-defined positions that characterise much political thought. Those more familiar positions infer that because 'A would be better than B, therefore we should replace B by A'. ${ }^{47}$ A conservative disposition denies the inference, but need not deny ' $\mathrm{A}$ is better than B'. It rather supplies a new way of reasoning about change by substituting the inference with some complexity in assessing whether, when, how, why, and how much to replace B with $\mathrm{A}$. In this respect, the opposite of a conservative disposition is not liberalism or socialism or any other philosophy, ideology or doctrine with a clear reforming agenda. ${ }^{48} \mathrm{~A}$ conservative disposition opposes itself less to any given 'ought demand' (though it may query assumptions animating such demands), but more to the evaluation of whether to pursue the demand and the manner in which it is pursued. In short, a conservative disposition involves a way of assessing the case for change; it is not, as a misleading simplification would have it, invariably opposed to change. We aim to correct this simplification by considering how this disposition responds to 'the problem of change'.

\section{The Problem of Change}

A conservative disposition is concerned with the problem of change: that is, how to assess the case for change, how much

to pursue at any given time, and on the strength of what reasons. To clarify, our appeal to 'problem' is not to an unwelcome or harmful situation, but to an inquiry for consideration. We seek to highlight how this disposition contributes to the inquiry by supplying evaluations beyond those regularly offered in support of change. It is often wrongly assumed that a conservative disposition towards change is negative and oppositional. ${ }^{49}$ Properly understood, this disposition involves 'a positive engagement'50 with change, furnishing arguments that recognise that change is inevitable and often desirable. As Burke noted, '[a] state without the means of some change is without the means of its own conservation'. ${ }^{51}$ The problem of change, then, is concerned with assessing the scope, extent, motivation, and need for change. A

\footnotetext{
${ }^{47}$ Cohen (n12) 220.

${ }^{48}$ Huntington (n18) 458.

${ }^{49}$ This view has sometimes been encouraged by conservative thinkers; see eg Huntington (n18) 461.

${ }^{50}$ Stefan Andreasson, 'Conservatism' in Vincent Geoghegan and Rick Wilford (eds), Political Ideologies: An Introduction (4th edn, Taylor \& Francis 2014) 47, 49.

${ }^{51}$ Burke (n13) 106.
} 
conservative disposition is seized by the complexity of such questions and offers open-ended guidance on how to answer them. By elaborating on traditionalism, scepticism, and organicism, we explain how this disposition reflects on the different qualities of change, among them: between improvements and innovations, between evolutions and replacements, between what is intimated by circumstance and what is imposed by principle, between redress and perfection, and between the gradual and ongoing changes immanent in prevailing arrangements and the planned and explicitly designed changes to those same arrangements.

\section{Traditionalism}

A conservative disposition is oriented to the fact that what now exists has value. ${ }^{52}$ It signals a refusal to treat established arrangements merely as instantiating a value that could be instantiated in some other way or in other arrangements. "The conservative impulse', on Cohen's view, 'is to conserve what is valuable, that is, the particular things that are valuable'. ${ }^{53}$ This impulse is inconsistent with keeping arrangements only for so long as 'nothing even slightly more valuable comes along'. ${ }^{54}$ A conservative disposition will value and seek to preserve 'the particular bearers of value' and has reason to resist dispensing with them and to regret their 'destruction as such,' a reason that one would not have if the particular bearers of value were valued only for the value that they bear or instantiate. ${ }^{55}$ By way of illustration, it would be to devalue a friend to maintain a friendship only for so long as no better friend comes along. ${ }^{56}$ To lose a friend is a cause for regret even if new and greater friendships are subsequently formed.

There is another way of approaching the thought that what now exists has value: the special relationship between someone and something. Our arrangements, institutions, and ways of doing things have value in the sense just reviewed: they have the value that any valuable arrangements, institutions, and ways of doing

\footnotetext{
${ }^{52}$ If what now exists has no (or negative) value, then traditionalism does not ground a conservative disposition.

${ }^{53}$ Cohen (n12) 210. For criticism of aspects of Cohen's account, see Brennan and Hamlin, 'Conservative

Value' (n30).

${ }^{54}$ Cohen (n12) 210.

${ }^{55}$ Cohen (n12) 210. See also Samuel Scheffler, Equality and Tradition: Questions of Value in Moral and Political Theory (OUP 2010) $26 \mathrm{ff}$.

${ }^{56}$ Cohen (n12) 210 and 211. See also Oakeshott, 'On Being Conservative' (n3) 416-17.
} 
things do. And yet, for us, they may have special value by virtue of being ours. ${ }^{57}$ The English language has value in facilitating communication and, in this respect, so do all languages. However, English language speakers will value the English language 'in a more personal way'. ${ }^{58}$ Even if, on the merits of facilitating communication, German is better than English, English language speakers with a conservative disposition would not seek to change their language, and not only because of the travails of doing so. The English language is theirs and they value it in part because it is the language that they speak. Its imperfections do not count against it in this way of valuing it; its comparative inferiority as a medium of communication does not decrease its value to them. This value relates to it being known and experienced by them and is not reducible to other evaluations.

In these two ways, a conservative disposition highlights the loss that accompanies change: the loss of something of value, and the loss for someone of something of value. ${ }^{59}$ This helps formulate a conservative argument for the problem of change: the loss that accompanies change. This argument highlights the special problem of change that is commonly missed by those who too quickly infer that 'A ought to replace B' because 'A is better than B'. By identifying value in things as they are and as reflected in the attachment of persons, this argument complicates the case for change.

Contrary to what may be assumed, this does not deny that change is regularly justified. The loss of value may be great or small. Prevailing arrangements may break down. There may be widespread and sustained dissatisfaction with the status quo. Maintaining arrangements in their current state may be burdensome or unsustainable. ${ }^{60}$ In short, a conservative disposition is always aware that change may be justified. But the questions whether, how, when, why, and how much to change are open, and this disposition brings to bear a distinctive evaluation of the likely gains and sure loses from pursuing reforming projects. ${ }^{61}$ For one with a conservative disposition, 'some things have to just be, they have to just be there, if anything is to

\footnotetext{
${ }^{57}$ One aspect of this thought is sometimes captured by the idea of 'sentimental value'.

${ }^{58}$ Cohen (n12) 223. See also Oakeshott, 'On Being Conservative' (n3) 408-10.

${ }^{59}$ Cohen's labels for these two categories of value are 'particular value' and 'personal value'.

${ }^{60}$ For a useful discussion, see Kekes (n10) 13.

${ }^{61}$ See Brennan and Hamlin, 'Analytic Conservatism' (n20) 679; Oakeshott, 'On Being Conservative' (n3) 411.
} 
be good'.62 In turn, if the existing arrangements have value for us, then we have reason to change slowly and to adjust gradually and patiently, rather than in a wholesale manner. We can accommodate changes to our language without losing our attachment to it, and without denying that it remains our language. But we cannot replace our language and maintain the thought that the new language is ours too. We may, in time, appropriate what is new and value it as ours, but at the moment of wholesale change we will have lost the value of something familiar and replaced it with something that is not. In this way, a conservative disposition affords continuity and stability, and it disciplines our approach to change by resisting the thought that everything is always 'under review', ${ }^{63}$ even as it acknowledges that nothing is ever immune from the possibility of change.

\section{Scepticism}

A conservative disposition favours wisdom drawn from accumulated experience. It is possible to derive from this three conservative arguments relating to the problem of change. First, scepticism counsels modesty, caution, and sobriety when considering reform. It is suspicious of the grand reformer, the 'presumptuous man', the 'true believer', and 'those who have never experienced a wisdom greater than their own'. ${ }^{64}$ There is hubris in the thought that, in proposing reforms to that which has lasted for generations, one person's 'private stock of reason' is greater than the 'general bank and capital of nations and of ages' ${ }^{65}$ The 'pride of the human intellect', Burke wrote, 'with all its defects, redundancies, and errors, is the collected reason of the ages' ${ }^{66}$ In respect of those complex arrangements that are not open to any one person, or even a single generation, to create (a peaceful community, constitutional government, the rule of law), there is all the more reason to exercise 'infinite caution' before 'ventur[ing] upon pulling down an edifice which has answered in any tolerable degree, for ages the common purposes of society'. ${ }^{67}$

\footnotetext{
${ }^{62}$ Cohen (n12) 223 (emphasis in original).

${ }^{63}$ Cohen (n12) 223.

${ }^{64}$ Burke (n13) 193. See also Huntington (n18) 460.

${ }^{65}$ Burke (n13) 183.

${ }^{66}$ Burke (n13) 193.

${ }^{67}$ Burke (n13) 152.
} 
Second, a conservative disposition is sensitive to the standing risk of many wrong turns in human reasoning. Wrong turns have many causes, including the failure to grasp every nuance of existing states of affairs, the imperfect ability to grasp the significance of circumstances, and the imperfect ability to account for the wisdom of experience. Considerations such as these are often discounted because the truth found in concrete experience is difficult to translate into general propositions. Many aspects of human experience - tacit knowledge, implied understandings, nuances of social practices—-do not lend themselves to ready formulation. Taken together, these imperfections signal the standing risk that 'man's hopes are high, but his vision short'. ${ }^{68}$ When it comes to change, not every promised benefit is realised and not every unintended side-effect is anticipated. Almost without exception, the total change is 'more extensive than the change designed'. ${ }^{69}$ All of this points to the risk that change will be mismanaged. The mismanagement of change may be great or small, depending on what is being changed. However, a conservative disposition cautions that 'the work of destruction is quick, easy and exhilarating; the work of creation slow, laborious and dull'.70

Third, under a conservative disposition, the case for reform is assessed against the more gradual, subtle, and constant changes that accompany all human practices. The presumption is that existing arrangements should not be lightly displaced, but this rests on the judgment that existing arrangements are 'constantly being subjected to the test of experience'. ${ }^{71}$ The presumption is that there is something to be said in favour of arrangements that work passably well. Where change is judged appropriate, a conservative disposition is 'corrective rather than innovative' insofar as it is directed primarily at repairing prevailing arrangements rather than introducing wholly new arrangements. ${ }^{72}$ There will, for sure, be tricky questions about whether a proposed change is corrective or innovative, as well as about the changes required in order to maintain things as they are..$^{73}$ But these are questions that, under this disposition, cannot be answered in the abstract but only after a careful analysis of the actual working of current arrangements. For these reasons,

\footnotetext{
${ }^{68}$ Huntington (n18) 456.

${ }^{69}$ Oakeshott, 'On Being Conservative' (n3) 411.

${ }^{70}$ Scruton, How to be a Conservative (n5) viii-ix.

${ }^{71}$ Pocock (n34) 131.

${ }^{72}$ Kekes (n10) 13.

${ }^{73}$ We return to what might be called 'renovative' change in section 6 below.
} 
this posture towards change is sometimes termed 'organic' rather than 'artificial'. ${ }^{74}$ Decisions about whether change is required, and if so the type and extent of change, should generally be justified on the grounds of experience. ${ }^{75}$ Change should be directed not at vindicating abstract principles, but at addressing challenges arising through experience. This recalibrates how imperfect arrangements are assessed: recognising that current arrangements should be assessed in the round and in terms of the historical record increases the willingness to conserve arrangements found wanting if assessed primarily against abstract principles.

\section{Organicism}

In Burke's account, society is a 'partnership not only between those who are living, but between those who are living, those who are dead, and those who are to be born'. ${ }^{76}$ Burke denied that society is 'nothing better than a partnership agreement in a trade of pepper and coffee $[\ldots]$ or some other such low concern, to be taken up for a little temporary interest'. ${ }^{77}$ Rather, it is a partnership of far greater ambition: a partnership in all science, all art, every virtue, and all perfection. ${ }^{78}$ This account of the community points to a conservative vision of a good society, albeit not one of the same order as the visions of end-defined political philosophies: it denies that the community has a specific end, enterprise or goal that one can plan to achieve in one lifetime or many. ${ }^{79}$ Governing a community is not like achieving a definite plan with efficient means and stipulated ends; governing is a responsibility for its members and their intermediate associations and their pursuit of ends. Institutions have a very special role in furnishing the stability and continuity that enables the community's members to pursue their own ends.

This in turn highlights the significance of certain conservative arguments respecting existing institutions and their reform: on the value of what exists, on the value for us

\footnotetext{
${ }^{74}$ See generally Quinton (n29). See also O’Hara (n5) 74.

${ }^{75}$ As captured by Burke, 'to any thing which relates to human actions, and human concerns', it is not the 'nakedness and solitude of metaphysical abstraction' but rather circumstances that give to 'every political principle its distinguishing colour, and discriminating effect': Burke (n13) 90.

${ }^{76}$ Burke (n13) 194-95.

${ }^{77}$ Burke (n13) 194.

${ }^{78}$ Burke (n13) 194.

${ }^{79}$ See Oakeshott, 'On Being Conservative' (n3) 422-34 and, more generally, Michael Oakeshott, On

Human Conduct (Clarendon Press 1975).
} 
of what is here and now, and on the complexities of grasping the whole of the problem of change. When reforms have as their purpose or effect the activities of others, it is important to be cautious not to think 'of making men, and binding nature to our designs'; rather, one should heed Burke's reminder that '[p]lans must be made for men'. ${ }^{80}$ Those men and women are already situated within existing institutions. Before proposing reforms to those institutions, it is necessary to 'see all the aids and all the obstacles', one must 'know the power and disposition to accept', one must 'see the things', one must 'see the men' ${ }^{81}$ This understanding of the management of political affairs recalls the idea that politics is the art of the possible, not the science of perfection. The powerful images of Neurath's ship at sea and Schiller's running clock recall that, in political affairs, we are already situated: we rebuild the ship at sea; we repair the clock during its rotations. ${ }^{82}$

Underpinning this is the recognition that prevailing institutions are more complex than commonly appreciated. Prevailing institutions express knowledge and experience accumulated over generations. In line with the conservative theme of scepticism, institutions encapsulate wisdom and furnish structure, stability, continuity, and (in the best of cases) unity in ways seldom fully understood. ${ }^{83}$ This is vital in enabling people to pursue their own vision of the good life. Part of the complexity of the community lies in the fact that no single institution can be regarded as a wholly discrete entity that can be changed without knock-on consequences for other arrangements. ${ }^{84}$ Echoing traditionalism, this suggests that because of their interconnected nature, institutions often have a value stretching beyond perfunctory assessments whether they fulfill their primary function. ${ }^{85}$ Institutions that have endured through time with a reasonable-but, inevitably, an imperfect-record will create a rebuttable presumption to support them. This presumption is justified not on the basis that the relevant institutions are traditional

\footnotetext{
${ }^{80}$ Burke (n13) 283.

${ }^{81}$ Burke (n13) 283.

${ }^{82}$ See Otto Neurath, Anti-Spengler (Callway Verlag 1921); Friedrich Schiller, On Aesthetic Education of Man (Crossroad 1990 [1794]) Letter 3.

${ }^{83}$ See Jeffrey Z Muller, 'Introduction: What is Conservative Social and Political Thought?' in Jeffrey Z Muller (ed), Conservatism: An Anthology of Social and Political Thought from David Hume to the Present (Princeton UP 1997) 3, 11.

${ }^{84}$ See Norton (n37) 93-94.

${ }^{85}$ See Philip Norton and Arthur Aughey, Conservatives and Conservatism (Temple Smith 1981) 27. See also Brennan and Hamlin, 'Analytic Conservatism' (n20).
} 
or long-standing, but because there is evidence that they have been tried and tested, and found to contribute to the community, even if imperfectly so.

\section{Three Criticisms}

Having outlined the conservative disposition, we now consider three criticisms. The first views this disposition as unattractive insofar as it is said uncritically to preserve vested interests, social and political inequality, and other undesirable states of affairs. On this view, this disposition has 'little appeal' to those discontented with the status quo, ${ }^{86}$ especially the underprivileged, the impecunious, or those who see no value or much disvalue in the current ways of doing things. A conservative disposition, on this critique, places too little weight on those who see no or negative value in existing arrangements, and entails the unreflective acceptance of those arrangements without subjecting them to critical scrutiny. ${ }^{87}$

This criticism overlooks the fact that all arrangements are subject to critical scrutiny under this disposition. That scrutiny is constant and immanent: no institution is immune from the possibility of change. ${ }^{88}$ Conservative arguments speak to an assessment of the merits and manner of change, but do not deny the many realities and necessities of change. They call for an assessment framed by an all-thingsconsidered appreciation of the value of prevailing arrangements, including an appreciation that some see no value in those arrangements. ${ }^{89}$ Arrangements are valued (if they are) not because they are long-standing, but because, if assessed in the round, they have helped to foster good states of affairs. Where that good state of affairs has been only partial or otherwise imperfect, the case for change is to prefer to improve existing arrangements, not to overhaul them. This preference can be overcome, for example when current arrangements contribute only negligibly to the good of the community, including where the least well off fare least well under those arrangements. ${ }^{90}$ Complicating matters is that the full repercussions of change take time to unfold, and frequently do so in contradictory ways. Overhauling existing

\footnotetext{
${ }^{86}$ Huntington (n18) 457.

${ }^{87}$ See Eccleshall (n6) 66.

${ }^{88}$ As Mannheim notes, a conservative disposition is not unreflective or 'the simple habit of living more or less unconsciously': Karl Mannheim, Conservatism: A Contribution to the Sociology of Knowledge

(David Kettler, Volker Meja and Nico Stehr (eds), Routledge 1986) 101.

${ }^{89}$ See Kekes (n10) 8.

${ }^{90}$ See Kekes (n10) 15.
} 
institutions is likely to lead to unforeseen consequences, some of which may be undesirable. Whichever arrangements are ultimately selected, however, be they now prevailing or newly imagined, there will inevitably be imperfections.

A second criticism questions whether the disposition provides sufficient guidance about change. Critics doubt whether it is ever possible for a conservative disposition to discern which parts of the current arrangements to conserve and which to change. After all, prevailing arrangements are complex and comprise intertwined threads. Complicating matters further is that various threads may already be changing in subtle ways that are difficult to discern. Such concerns lead some to question whether this disposition can ever operate as a practical guide to manage change in a complex community. The disposition, in other words, fails to offer 'an adequate explanation of deliberate change'. ${ }^{91}$

A conservative response stresses that it is precisely concerns such as these that should form part of the evaluation whether to preserve prevailing arrangements that over the years have contributed to the community. It is the difficulty of knowing exactly what to change that encourages a discerning approach. That it is difficult to craft an account of deliberate change is not to refute a conservative disposition, but to affirm its central arguments. Those criticising this disposition for furnishing insufficient guidance tend to harbour unrealistic expectations about the sort of guidance that can ever exist about whether, when, how, why, and how much to change. The complexity of prevailing practices, along with the fact that the consequences of change cannot be confidently predicted, suggests that only limited guidance can ever be offered about when change is justified. Sound assessments of the case for change must instead be concrete and corrective.

A third critique suggests that a conservative disposition lacks coherence. Here, the disposition is criticised for responding to change differently depending on when it occurs. If change has already occurred it now forms part of the status quo that enjoys a presumption that it ought to be conserved, whereas proposals for future change are viewed with suspicion. For critics, this implies incoherence at the heart of

\footnotetext{
${ }^{91}$ Nevil Johnson, 'Constitutional Reform: Some Dilemmas for a Conservative Philosophy' in Zig LaytonHenry (ed), Conservative Party Politics (Macmillan 1980) 127.
} 
conservative thought. It also suggests an asymmetry in the assessment of change insofar as the disposition seems to neglect the risks of not changing. A related criticism suggests that a person confronting the prospect of future change stands on shifting sands, insofar as attempts to improve prevailing arrangements via a corrective approach to change almost inevitably end up implementing solutions that reform more fully than anticipated, involving the sort of innovative approach that the disposition purports to eschew. ${ }^{92}$

This misreads how a conservative disposition assesses the relationship between past and future change. For a start, claims of incoherence hold only if a conservative disposition is insensitive to context; as an assessment of what now prevails and of potential changes, there is no incoherence in looking differently to past and future changes. ${ }^{93}$ What now exists has value and the case for change is subject to critical scrutiny. In turn, any risk of inaction must be similarly assessed and it will sometimes be concluded that maintaining present arrangements in fact requires positive action, a complication to which we return in section 6 . As for the risk that efforts to improve existing arrangements often involve much more extensive reform than anticipated, here too the conservative reply is to acknowledge that this is a standing possibility, but to recall that this is amongst the reasons why it is necessary to adopt a prudent and clear-headed approach to change of the sort associated with this disposition.

\section{An Eclipse in Constitutional Thought}

We now consider the standing of this disposition within constitutional thought. The connections between the UK's customary constitution and a conservative disposition were at one time strong. For much of the twentieth century, the three core conservative themes resonated within a constitution widely regarded as 'a summation of political experience' and 'substantiated by longevity, continuity, assimilation and adaptation'. ${ }^{94}$ Parliamentary government embodied traditionalism (by recognising the political value expressed within long-standing institutions),

\footnotetext{
${ }^{92}$ Johnson (n91) 129.

${ }^{93}$ See Huntington (n18); Beckstein 'What does it take to be a true conservative?' (n18) 9-10; Brennan and Hamlin, 'Conservative value' (n30) 367.

${ }^{94}$ Michael Foley, The Politics of the British Constitution (Manchester UP 1999) 1.
} 
scepticism (by embracing the constitution as an inherited 'political way of being'95 rather than a rational design grounded on abstract principles), and organicisim (as reflected in the tradition of the 'mixed constitution', with actors cautious before interfering with intricate institutional balances). The leitmotif was evolutionary adaptation, with parliamentary sovereignty serving as an expression of 'constitutional gradualism'. ${ }^{96}$ These connections were reinforced by and helped to buttress the ways in which politicians, judges, officials, and lawyers conceived change. Most operated within the tried and tested ways of doing things, preferred to regulate via conventions, and were reluctant to overhaul the constitution, preferring to absorb change within prevailing institutions. This is to say nothing of law's emphasis on the authority of historic sources and, more particularly, the disposition's connections with the common law, viewed as a corpus of case law that incrementally develops by extrapolating the accumulated practical knowledge of the community. ${ }^{97}$

The contemporary constitution presents a very different context. ${ }^{98}$ No longer are there such strong connections with conservative themes and fewer actors seem to embrace a conservative disposition towards change. This is reflected not only in the 'unprecedented' volume of reform in a short space of time, ${ }^{99}$ but also in the substance of many of those reforms. It is only a slight exaggeration to suggest that the reforming spirit has touched almost all corners of the constitution, including by: creating a new tier of devolved government; reforming the House of Lords; introducing fixed dates for parliamentary general elections; enacting a statutory bill of rights; reforming the appointment, funding, and leadership of the courts; using referendums to answer constitutional questions; and abolishing some long-standing institutions (the judicial House of Lords) and reshaping others (the Lord Chancellor). This is to say nothing of the reconfiguration of executive functions inside Whitehall and beyond. Over and above this, parliamentary sovereignty is

\footnotetext{
${ }^{95}$ Martin Loughlin, 'Constitutional Theory: A 25 ${ }^{\text {th }}$ Anniversary Essay' (2005) 25 OJLS 183, 184.

${ }^{96}$ Neil Walker, 'Our Constitutional Unsettlement' [2014] PL 529, 530-531.

${ }^{97}$ In some of his work, Martin Loughlin explains the connections between the common law method and the UK's customary constitution in ways that draws out some of the characteristics of a conservative disposition. See Martin Loughlin, Legality and Locality: The Role of Law in Central-Local Government Relations (Clarendon 1996) 375; and Martin Loughlin, 'Rights Discourse and Public Law Thought in the UK' in GW Anderson (ed), Rights and Democracy: Essays in UK-Canadian Constitutionalism (Blackstone 1999) 194-195. We discuss similar themes in Gee and Webber (n17) 720-730.

${ }^{98}$ See generally Grégoire Webber, 'Eulogy for the constitution that was' (2014) 12 ICON 468.

${ }^{99}$ Mike Finn and Anthony Seldon, 'Constitutional Reform Since 1997: The Historians' Perspective' in Matt Qvortrup (ed), The British Constitution: Continuity and Change (Hart 2013) 17, 18.
} 
increasingly questioned and the UK's relationship with the EU continues to cause constitutional tremors.

Interpretations of the significance of these reforms differ. For some, the reforms stress continuity as much as change, not least insofar as they have been framed as consistent with parliamentary sovereignty and the Westminster model. ${ }^{100}$ For others, their cumulative consequence is to remake arrangements to such an extent that it is apt to talk of a 'new' constitution. ${ }^{101}$ There are still others who regard the reforms as blending change with continuity, but with assessments differing whether the resultant blend is a success or a 'mess'. ${ }^{102}$ For our part, the reforms- their volume, their frequent justification in terms that privilege abstract principles over the constitution's concrete workings, and the seeming scant regard for spillover effects—-suggest the eclipse of a conservative disposition.

By design we speak of the 'eclipse' of this disposition: its significance has receded, but its influence is not altogether absent. Consider the Constitutional Reform Act 2005. At one level, the Act resoundingly rejected core conservative themes. The Act failed to value the tried and tested overlapping roles of the Lord Chancellor (contra traditionalism). Overhauling this office and replacing the House of Lords with a Supreme Court were justified not on the basis that the then existing arrangements no longer worked, but by reference to generalizations on judicial independence and the separation of powers (contra scepticism). These reforms suggested a failure to grasp how the then prevailing arrangements reinforced shared understandings amongst constitutional actors about how the rule of law and judicial independence had been secured within the inherited institutional landscape (contra organicism). ${ }^{103}$ At another level, conservative arguments shaped the final content of some of the reforms. The Government initially sought to abolish the Lord Chancellor, but ultimately settled on a substantially reshaped office largely in response to arguments that the desired changes should be accommodated within a retained but revised

\footnotetext{
${ }^{100}$ See eg Mark Evans, Constitution-Making and the Labour Party (Palgrave Macmillan 2003); and Matthew Flinders, Democratic Drift: Majoritarian Modification and Democratic Anomie in the UK (OUP 2009).

${ }^{101}$ See eg Vernon Bogdanor, The New British Constitution (Hart 2009).

${ }^{102}$ See Anthony King, The British Constitution (OUP 2007), especially chapter 14.

${ }^{103}$ See Dawn Oliver, 'The Lord Chancellor as Head of the Judiciary' in Louis Blom-Cooper, Brice Dickson and Gavin Drewry (eds), The Judicial House of Lords 1876-2009(OUP 2009) 97.
} 
office. ${ }^{104}$ This illustrates a larger pattern in which the conservative disposition is marginalised within contemporary approaches to reform, but continues to influence the reforms ultimately adopted. ${ }^{105}$

A number of critiques of the conservative disposition's contributions to constitutional change help account for its eclipse in public law. Of note is that, in contrast to their predecessors, many public lawyers today seem to regard a conservative disposition to constitutional change as symptomatic of constitutional failure. ${ }^{106}$ The crudest critique dismisses this disposition as unreflective and without intellectual foundation. Such an approach to change is misrepresented as accidental or unthinking, as if involving no explanation for, justification of, or even assessment of the way things are. ${ }^{107}$ This is not a serious critique. ${ }^{108}$ As we have argued, intellectual commitments and arguments about value, knowledge, and institutions inform a conservative disposition. They may not strike everyone as sound or convincing, but this disposition, properly conceived, entails a reflective assessment of the problem of change.

A more interesting and challenging set of critiques acknowledges that a conservative disposition might have furnished an intelligible approach to change when the UK enjoyed a relatively 'settled constitution', ${ }^{109}$ but argues that this is no longer the case. One such critique suggests that attempts to accommodate change within a

\footnotetext{
${ }^{104}$ See generally Lord Windlesham, 'The Constitutional Reform Act: The Politics of Constitutional Reform-Part 2' [2006] PL 35.

${ }^{105}$ It also illustrates the complex relationship between deliberate change (such as the $2005 \mathrm{Act}$ ) and the often more difficult to detect ongoing change (such as the changes to the judicial review over fifty years, changes to the office of Lord Chancellor across the twentieth century, and changes to the appointment of judges in the 1990s, all of which provided the backdrop to the 2005 reforms). On one reading, the 2005 Act was an extension of ongoing changes; or, in Oakeshottian terms, the reformers pursued what was intimated in the constitutional traditions of behaviour that developed across the twentieth century. We keenly acknowledge that there is a complex interplay between change and continuity, but our view is that this misreads the extent of the 2005 reforms, and the motivations and reasoning of the reformers, as argued in Gee and Webber (n17) 729. On the interaction of change and continuity within recent reforms, see Matthew Hall, David Marsh, and Emma Vines, 'A Changing Democracy: Contemporary Challenges to the British Political Tradition’ (2018) 39 Policy Studies 365.

${ }^{106}$ An exception is J.W.F. Allison, The English Historical Constitution: Continuity, Change and European Effects (CUP 2007).

${ }^{107} \mathrm{~A}$ case of 'muddling by' or, in Bagehot's terms, 'stumbling upon' constitutional arrangements. See Walter Bagehot, The English Constitution (first published 1867, OUP 2009) 10.

${ }^{108}$ This does not deny that political and judicial actors may view change in opportunistic and strategic terms. See generally Dawn Oliver, 'The United Kingdom' in Dawn Oliver and Carlo Fusaro (eds), How Constitutions Change: A Comparative Study (Hart 2011) 325.

${ }^{109}$ Walker (n96).
} 
narrative of continuity distort how the constitution is understood by tending to overstate continuity and understate discontinuity. For Christine Bell, the propensity to claim change as continuity in what some assume is the manner of the conservative disposition is the 'essence of British constitutionalism', but 'also operates to deny alternative narratives of rupture'. ${ }^{110}$ Bell cites the contested territorial constitution, where a narrative of continuity (devolution coheres with parliamentary sovereignty; conventions regulate institutional relationships; broad constitutional consensus and shared political identities prevail) conceals the full extent of the discontinuity (devolution institutionalises new political communities with divergent policy agendas and distinct political identities, with rival and opposing perspectives on the constitution hardening as a result). ${ }^{111}$

This critique highlights the difficulty of assessing the respective degrees of continuity and change in a historic constitution. Change may occur in one area of the constitution but not others. Continuity in one area might restrict the scope for change in another, whilst change in some area may erode continuity in another. All of this is true. ${ }^{112}$ But the difficulty of mapping the relationship of change to continuity, and discerning one from the other, holds for all approaches to change, conservative or radical or other. A conservative disposition does not have an in-built bias in favour of claiming change as continuity. Properly understood, it involves the reflective and ongoing examination of the various elements of political life to work out what is (and should be) changing and what is (and should be) staying the same. Rather than having an in-built tendency to claim change as continuity, this disposition underscores the ways in which change is conditioned and channelledand it recognises that, in a customary constitution, continuity will provide the essential context in which change occurs and in that way will affect the nature and extent of change.

\footnotetext{
${ }^{110}$ Christine Bell, 'Constitutional Transitions: The Peculiarities of the British Constitution and the Politics of Comparison' [2014] PL 446, 457.

${ }^{\text {"II }}$ See further Aileen McHarg, 'The Constitutional Case for Independence' in Aileen McHarg, Tom Mullen, Alan Page and Neil Walker (eds), The Scottish Independence Referendum: Constitutional and Political Implications (OUP 2016) 101, 107; Aileen McHarg and James Mitchell, 'Brexit and Scotland' (2017) BJPIR 1, 13.

${ }^{112}$ See David Marsh, 'Stability and Change: the Last Dualism?’ (2010) 4 Crit Pol Stud 86.
} 
A related critique suggests that prevailing political and legal conditions are no longer conducive to a conservative disposition, unlike the conditions that prevailed for much of the twentieth century. ${ }^{113}$ The constitution is no longer the subject of consensus. Parties contest constitutional policy at multiple tiers of government, offering competing and even incompatible constitutional visions, with the language of 'crisis' now a familiar part of the lexicon. ${ }^{114}$ Constitutional reform-including over the UK's future relationship with the EU, territorial integrity, rights protection, and electoral reform-enjoys an electoral salience unrivalled since debates over Home Rule and the House of Lords at the beginning of the twentieth century. Fundamentals such as parliamentary sovereignty and the unitary state are increasingly questioned. The legitimacy and effectiveness of the constitutional apparatus can no longer be taken for granted, with this unleashing pressures for reform that are increasingly difficult to contain within incremental approaches to change.

According to this critique, in a political climate where there are electoral imperatives to propose reforms to address perceived deficiencies in the constitutional system, it becomes difficult not only to uncover much evidence of a conservative disposition, but to locate sufficient political and legal space for such a disposition to take hold. For a start, there is simply too much change to too many parts of the constitution for a conservative disposition to offer reliable guidance about how to respond to persistent pressures for reform. On this account, with so much reform having already occurred, with significant changes still ongoing, and with popular pressures for further change still unmet, the constitutional landscape is insufficiently stable for a conservative disposition. It is too difficult to work out which arrangements to conserve and which to change, and too challenging to calibrate changes that might improve prevailing arrangements without too many undesirable effects. According to this critique, the prevailing conditions will become less and less conducive to a conservative disposition over time as the dynamic of constitutional reform feeds itself. ${ }^{115}$

\footnotetext{
${ }^{113}$ Notably, the broad consensus that straddled the governing parties, reinforced by the constitutional incrementalism of parliamentary sovereignty.

${ }^{1 "}$ See eg DJ Galligan (ed), Constitution in Crisis: The New Putney Debates (IB Tauris 2017).

${ }^{115}$ Walker (n96) 540-541.
} 
This is a challenging critique. We recognise that political and legal conditions mean that, for many, a conservative disposition no longer has the same appeal. We also recognise that, other things being equal, the assessments about whether, how, when, how much, and when to change are easier in the context of a reasonably settled constitution. But we resist the suggestion that a conservative disposition has lost its relevance in times of change and uncertainty. To illustrate the persistence of its contingent but important guidance for public lawyers striving to make sense of a changing constitution, we reflect on two proposals for significant constitutional reform favoured by some public lawyers: the withdrawal of the UK from the European Convention on Human Rights and a written constitution. We argue that a conservative disposition remains relevant for assessing the case for change promoted by those who favour one or the other constitutional reform.

\section{Conservative Arguments for a Changing Constitution}

We have sought to identify conservative arguments relating to change that are intimated by traditionalism, scepticism, and organicism. None of these arguments oppose change indiscriminately. Taken together, they contribute to assessing whether, how, why, to what extent change should be pursued, and when. This last consideration is especially relevant to a constitution in flux. A conservative disposition encourages proposals for change to be evaluated in the light of both the deliberate changes that have been planned and the continuous pattern of immanent change that characterises any complex community. In the constitutional context, this encourages would-be reformers to determine whether to pursue planned changes now or after observing how ministers, Parliament, courts, and others have adapted to the changes already underway. This lesson is important at all times, but especially when deciding whether to pursue change shortly after far-reaching reform.

Consider the proposal to withdraw from the ECHR. For some, leaving the EU is an assertion of democratic self-government that heralds the potential to reaffirm elements of the customary constitution, in part by reasserting the primacy of national political authorities and recalibrating the UK's relationship with 
international legal regimes and powerful international courts. ${ }^{116}$ Read this way, the case for withdrawing from the ECHR can be seen as a continuation of this larger enterprise and, in this, a reform that 'goes with the grain' of (at least soon to be) prevailing arrangements. However, conservative arguments caution against assessments that underplay fundamental shifts in constitutional affairs. Traditionalism argues that, for many, withdrawing from the EU marks the loss of a valuable, tried and tested (even if imperfect) relationship with international institutions and with the idea of shared European identity. Scepticism argues that the risk of mismanaging the change brought about by Brexit is real, with the consequences of the UK's future relationship with Europe impossible to predict with any certainty. The EU and the ECHR were both the work of many hands and although for some leaving the former is exhilarating, the work ahead will be laborious. Organicism points to the role of institutions in securing political and social order as a reason to be careful before changing too many institutions at once. This has a special relevance here, given that the UK's departure from the ECHR involves redefining many of the same international relationships as leaving the EU, and further risks disturbing internal relationships between central and devolved institutions. Taken together, and even granting (for the purposes of argument) that withdrawing from the ECHR is a desirable reform that 'goes with the grain' of Brexit, the conservative disposition highlights that the case for pursuing this change now must be assessed against the case for postponing such reform to some point in the future.

The current political and legal uncertainty signals a different case for a very different reform. For some public lawyers, the fragility of the UK's constitution, and especially the place of human rights and the status and privileges of the devolved institutions within it, does not herald the reassertion of the customary constitution; it underlines instead the need for a written constitution. ${ }^{117}$ Some entertain reforms that would comprehensively remake the historic constitution, viewing withdrawal from the EU as the prelude to a 'constitutional moment' that could lead to transformative change, ${ }^{118}$ culminating in a written constitution. Such a constitution

\footnotetext{
${ }^{116}$ See eg Richard Ekins, Brexit and Judicial Power (Policy Exchange 2017) 7.

${ }^{117}$ See eg Richard Gordon, Repairing British Politics: A Blueprint for Constitutional Change (Hart 2010).

${ }^{118}$ Vernon Bogdanor, Brexit and Our Unprotected Constitution (The Constitution Society 2018) 40. See also Vernon Bogdanor, Beyond Brexit: Towards a British Constitution (IB Tauris 2019).
} 
would be part codification, part clarification, and part reform. ${ }^{119}$ For its proponents, a written constitution would provide an opportunity to secure certainty, clarity, and the priority of constitutional principle in political and legal affairs and to award to the constitution a democratic mandate. ${ }^{120}$ All of this could be done, on one reading at least, in ways that 'might subsequently appear to be a natural outgrowth'121 of recent reforms.

A conservative disposition contributes, once again, to an assessment of this case for change by stressing the importance of evaluating change in light of the complexity of the whole constitutional system. The claim that this disposition is associated with slow and incremental change encourages some to mischaracterise it as inattentive to how discrete changes can have sizable systemic effects. The opposite is nearer the truth. An indispensable contribution of this disposition is that any purportedly discrete proposal for change should be considered in light of its implications for wider arrangements. Taking into account the complexity of political organisation tends to encourage an appreciation of the value of tried and tested constitutional arrangements that have endured through time with a reasonable if imperfect record. Those who advocate for a written constitution may deny that the present constitution is working well, but they are unlikely to deny that it has merit. Although for many public lawyers the 'present discontents' ${ }^{122}$ are real, few would argue that they match the conditions under which many of the world's written constitutions were adopted. Those conditions generally aligned with Burke's thought that far-reaching change can be justified on grounds of necessity to be measured on the basis of concrete political circumstances. ${ }^{123}$ Those concrete political circumstances should be assessed in the round and, when a proposal for change is evaluated in light of the complexity of the whole system, it often leads to a greater willingness to accept imperfect institutions, with the decision made to improve rather than upend the prevailing arrangements.

\footnotetext{
${ }^{119}$ See generally Vernon Bogdanor, Tarunabh Khaitan and Stefan Vogenauer, 'Should Britain Have a Written Constitution?' [2007] PQ 499.

${ }^{120}$ See eg Jeff King, 'The Democratic Case for a Written Constitution' (2019) CLP (forthcoming).

${ }^{121}$ Andrew Blick, 'The Merits of a Written Constitution' [2016] JR 49, 52. See also Robert Blackburn, 'Enacting a Written Constitution for the United Kingdom' (2015) 36 Statute L Rev 1; Graham Allen, 'Democracy-Defend Yourself or Die: A Response to Bruce Ackerman' (2018) 89 PQ 604.

${ }^{122}$ Martin Loughlin, 'The British Constitution: Thoughts on the Causes of the Present Discontents' (2018) 16 NZ J Public Intl Law (forthcoming).

${ }^{123}$ Burke (n13) 276.
} 
A willingness to accept (at least for now) imperfect arrangements is supported by conservative arguments. Traditionalism recalls that, though a written constitution may bring gains, change also brings losses, including the loss of an attachment to a constitutional tradition that has long distinguished the UK and given it a sense of identity. ${ }^{124}$ Scepticism recalls that the accumulated experience of the UK's customary constitution captures political wisdom and its evolutionary nature facilitates a close appreciation of the truth in experience, an appreciation that is harder to maintain when a constitution is adopted at a moment in time and eschews the sort of day-today evolution characteristic of a customary constitution. Organicism recognises that some changes have knock-on consequences that cannot be predicted with confidence. Again, these conservative arguments do not indiscriminately deny the case for change. Their contribution is to the assessment of the case for change, and that contribution is especially relevant (if also easy to overlook) when the UK is in the unusual position of having an unwritten constitution that works passably wellsufficiently well, at least, to allow us to consider whether we want a new constitution'. ${ }^{125}$ In short, the case for a written constitution, as with the proposal to withdraw from the ECHR, helps to explain why a conservative disposition remains relevant during times of constitutional change and uncertainty. The burden of crafting a compelling case for change may seem to be easier to meet in such times, but conservative arguments instead highlight how the case for change may in fact be weakened by too much change.

Our suggestion, then, is that conservative arguments are especially relevant at a time of change and uncertainty and hold for public lawyers with opposing assessments of our current constitutional condition. In the present constitutional context, there are two connected conundrums confronting any public lawyer who seeks to employ these arguments to the problem of change: first, how to determine when a 'past' constitutional reform is so bad that it should be undone; and second, how to determine when proactive change is required to prevent the atrophy of the constitutional status quo. What guidance-if any - does the conservative disposition provide in the face of these conundrums? Here, our starting point is to recall that the

\footnotetext{
${ }^{124}$ At last in large parts of the UK and many of its communities.

${ }^{125}$ NW Barber ‘Against a written constitution’ [2008] PL 11, 11.
} 
conservative disposition only ever offers open-ended and contingent guidance about how to respond to the problem of change; it furnishes arguments that complicate the case for change, but does not prescribe in detail the changes that should be made or not. A conservative disposition, as we understand it, advocates for conservative reasoning, but not for conservative answers or outcomes or policies.

On the first conundrum: on its face, undoing wrong-headed reforms seems to go against the grain of the conservative disposition. However, determining whether to undo some bad past reform is part of the problem of change, and it can be subjected to conservative reasoning. Under this reasoning, it is always possible to seek to undo past change where this is recommended by experience. This decision should only be taken after weighing up the risks associated with further change, with that assessment made on the basis of material considerations. It may ultimately be decided that the past change should not be undone because the high costs of that earlier change have already been incurred (and, indeed, might have been even higher if earlier conservative calls for gradual change had been neglected). ${ }^{126}$ In addition, a conservative calculus may suggest that, over time, the prevailing arrangements that are a partial product of past change may now have value worth conserving, either as particular bearers of value that cannot be treated merely as dispensable or as being known and experienced by persons. This recognises that further change would incur loss, which complicates the case for reform. Critically, these determinations must all be made by reference to actual workings of the constitution, not abstract principles.

The inclination is to be corrective rather than innovative. For example, rather than withdraw from the ECHR, a conservative assessment might suggest amending those provisions of the Human Rights Act that shape how the Strasbourg Court's case law is received into domestic law or how domestic courts should interpret Convention rights. But this inclination falls away if the conservative calculus suggests that the past reform is so 'bad' that it risks further undercutting other aspects of the constitution. In such a situation, the conservative disposition will countenance the more far-reaching change of undoing a recent reform in order to secure other aspects of the constitution. It may be, for example, that some public lawyers will conclude that repealing the Fixed Term Parliament Act 2011 is necessary in order

${ }^{126}$ See Peter King, The New Politics: Liberal Conservatism or Same Old Tories? (Policy Press 2011) 29. 
to reaffirm 'the confidence relationship' as a constitutive feature of parliamentary democracy in the UK. ${ }^{127}$ A key consideration during a period of flux will be to do this sensitive to what is realistic and prudent in the political and legal circumstances, including thinking about timing (ie whether to undo this past change now because the risk to the working of the constitution is so great, or to wait because the risks of destabilising other parts of the constitution are too great at this point in time). Complicating all of this is the need to assess the risks of both action and inaction, all the while recognising that the case for further deliberate change (including to undo previous reforms) must also be evaluated against the immanent change that accompanies all arrangements, as they are subjected to the cauldron of experience and shaped by environmental developments around them. ${ }^{128}$

This brings us to the second conundrum. Conservative thought has tended to offer little guidance on when proactive change is required to ensure things essentially remain the same. Much conservative thought draws overly stark contrasts between a supposedly stable quo and far-reaching change, where the former is maintained by resisting the latter. But sometimes the proactive pursuit of change is necessary to maintain the status quo. This is especially important where, for example, a changing external environment leads to the inadvertent transformation of prevailing institutions and practices. In such circumstances, 'renovative' change may be necessary: proactive change that is aimed at conserving current arrangements. ${ }^{129}$ The need to consider renovative change is especially important during a period of constitutional flux. After all, when the political and legal landscape is very fluid, there is a real risk that institutions will be transformed inadvertently unless action is taken to prevent such transformation.

There is much more work to be done to elucidate the guidance that a conservative disposition offers those deciding whether, how, and when to pursue renovative

\footnotetext{
${ }^{127}$ On the commonplace confusion about the status and extent of the confidence relationship following the enactment of the Fixed Term Parliament Act, see House of Commons Public Administration and Constitutional Affairs Committee, The Role of Parliament in the UK Constitution Interim Report: The Status and Effect of Confidence Motions and the Fixed Term Parliaments Act 2011 (2018) HC 1813. See also Philip Norton, 'The Fixed Term Parliament Act and Votes of Confidence' (2016) 69 Parl Aff 4 ${ }^{128}$ For an important recent contribution on the impact of environmental developments and the problem of change, see Martin Beckstein 'Political Conservation, or How to Prevent Institutional Decay', forthcoming in Constellations.

${ }^{129}$ The expression is from Beckstein, 'Political Conservation, or How to Prevent Institutional Decay' (n128).
} 
change. For now, we follow Martin Beckstein in suggesting that, all other things being equal, the case for renovative change is compelling where necessary to conserve the basic nature or function of the institution or an important part of it. ${ }^{130}$ Such a case will be especially powerful where the aggregate results of a series of discrete changes over time risk inadvertently transforming the constitution or part of it. For example, some now argue that renovative change is necessary to maintain (what they take to be) the good sense informing the traditional separation of powers between political and judicial institutions. On this view, the judicial function is at risk of being transformed as the cumulative consequence of a mix of deliberate change (such as the conferral of new powers on the courts under the Human Rights Act) and immanent change (such as changes in traditional legal reasoning as a result of the increasingly dominant place of proportionality and balancing in judicial reasoning). ${ }^{131}$ This has led some to argue for renovative change that would (on their view) stabilize the separation of powers. Others today debate whether electoral reform is necessary to preserve the executive-legislative relationship at Westminster in the face of the fragmentation of the party system together with the emergence of profound divisions on the UK's relationship with the EU that cross the traditional ideological divide. In such situations, the conservative disposition would countenance proactive change to institutional structures or cultures in order to conserve the basic nature or identity of that institution. In keeping with conservative responses to the problem of change, the decision to pursue renovative change must be based on material not abstract considerations, and must acknowledge that this carries all of the costs and risks attendant upon any change. The guidance provided by conservative reasoning is open-ended and eludes easy answers, but this is part of its contribution to the problem of change. By complicating the inference from ' $\mathrm{A}$ is better than B' to 'A ought to replace B', a conservative disposition helps public lawyers evaluate the complexity of constitutional change.

\section{Conclusion}

\footnotetext{
${ }^{130}$ Beckstein, 'Political Conservation, or How to Prevent Institutional Decay' (n128).

${ }^{131}$ See generally Richard Ekins and Graham Gee, 'Putting Judicial Power in its Place' (2017) 36 UQLJ 375. On the relationship of legal reasoning to proportionality and balancing, see Francisco Urbina, $A$ Critique of Proportionality and Balancing (CUP 2017) and Grégoire Webber, 'Rights and the Rule of Law in the Balance' (2013) 129 LQR 399.
} 
For much of the last century, constitutional thought exhibited a conservative disposition. Today, not only is its hold on constitutional thought waning, but many public lawyers no longer have a good understanding of it. We have sought to identify the main intellectual commitments of the conservative disposition, explaining how it offers open-ended guidance on the problem of whether, how, why, when, and how much to change. By reviewing the core themes of traditionalism, scepticism, and organicism, we have sought to tackle some commonplace misunderstandings of this disposition and, in so doing, bring into view arguments about change often overlooked in constitutional debates. We have also sought to reflect some of this disposition's subtleties that are absent from discussions that reduce conservatism to little more than 'a defence of lost causes'. ${ }^{132}$ A conservative disposition will not provide every insight needed to make sense of a changing constitution, but there is a very real risk of losing sight of important aspects of the constitution and its reform if distinctively conservative arguments are neglected. This risk is greatest at a time of high levels of change and uncertainty.

${ }^{132}$ Muller (n83) 423. 